\title{
Implementation of Tax Policy on Acquisition of Land And Building Rights in Bandung City
}

\author{
Poni Sukaesih Kurniati \\ Department of Government Science \\ Universitas Komputer Indonesia \\ Bandung, Indonesia \\ poni.sukaesih@email.unikom.ac.id
}

\begin{abstract}
Tax on Acquisition License The right to land and buildings (BPHTB) is one of the central government taxes that transferred its authority to the region after the birth of the Regional Tax and Retribution Law. In its implementation, the tax sourced from the duty of acquisition of land and building rights has not been explored optimally, so it has not been able to increase the value of Local Revenue in Bandung. Therefore, the purpose of this study is to analyze the extent to which the implementation of tax policy on the acquisition of land and building rights is seen from the factors of communication, human resources, bureaucratic structure, and disposition. The research method used is descriptive method qualitative approach. Data collection techniques through observation, in-depth interviews, and documentation. Triangulation techniques researchers use to check the validity and reliability of data. Data analysis techniques performed through data reduction, data display, and conclusion. The results showed that Bandung City has tried to increase the value of Local Revenue through the source of tax on the acquisition of land and building rights, but not maximized.Viewed from the communication aspect has been done socialization efforts by using various media, but not yet effective. Human resource factors are sufficient, but from the aspect of disposition must still be addressed related to commitment and responsibility. In the bureaucratic structure, the need for a bureaucratic arrangement in the tax service department to be more effective and efficient in exploring the potential of tax on the acquisition of land and building rights.
\end{abstract}

\section{Keywords - Policy Implementation, Tax, BPHTB}

\section{INTRODUCTION}

Since entering the reform era in 1998, cities and districts in Indonesia have the authority to organize and manage their own households. This is where the regional autonomy milestone begins with the principle of decentralization. Regional autonomy begins with the issuance of Law Number 24 year 1999 which was later amended into Law Number 32 Year 2004 and revised back into Law Number 32 Year 2014 on Regional Government. In addition, there is also a regulation on the financial division between the central government and the regions, with Law No. 25 year 1999 which was later amended into Law No. 33 year 2004 on Financial Balance between central and local government. The issuance of various laws and regulations is the basis for the government to perform its functions. The function of government is to do the service, empowerment and development.
The function of government in doing development, is one of the most crucial functions for a city. Bandung city is one of the cities in Indonesia that continuously perform development activities in various fields. The development carried out in the city of Bandung consists of development that is physical and human development. The source of funds to carry out this development is the tax. Therefore, it is further stipulated in Law Number 28 Year 2009 regarding Regional Tax and Levy.

Local tax is a compulsory levy on an individual or an entity carried out by a local government without a directly equal contractual contribution, which may be enforced under applicable legislation, which is used to finance the administration of local government and regional development (Rahayu ,2010) . Local taxes in Bandung city are regulated in Bandung Regional Regulation No. 6 of 2016 on amendments to City Local Regulation No. 20 of 2011. Regional taxes in the city of Bandung consists of 9 types of taxes are Hotel Tax, Restaurant Tax, Entertainment Tax, Advertising Tax, Street Lighting Tax, Parking Tax, Ground Water Tax, Land Acquisition Duty on Land and Buildings, Land Tax and Rural and Urban Buildings. Land and building taxes, as well as land and building acquisition fees (BPHTB) were originally a central government tax, but after the enactment of Law No. 28 of 2009 changed into local taxes.

Taxes generated from BPHTB is one of the major tax sectors in Bandung. Therefore the city of Bandung issued a Regional Regulation of Bandung No. 2 of 2011 on the Acquisition of Land and Building Rights (BPHTB). The land is a human residence that has social and economic functions, as well as buildings located on the ground. Acquisition of rights to land and buildings may occur due to the transfer of rights and grant of new rights.

Bandung started in 2011 to collect BPHTB after two years of ratification of Law Number 28 of 2009. It is based on Regulation of Directorate General of Tax Number: PER-47 / PJ / 2010 dated October 22, 2010, stating that since January 1, 2011, BPHTB changed to local taxes. Thus the region can manage BPHTB as a source of local taxes and will become one of the potential sources to increase Revenue Local in Bandung.

Based on the observation, the decrease in tax revenue from BPHTB is due to the implementation of BPHTB policy in Bandung has not been implemented properly. This is evident from the existence of several problems of socialization 
undertaken by the Government of Bandung has not been effective, the resources involved in limited tax collection activities.

Research on BPHTB has been studied by other researchers, including Hajarwati (2016) conducted a study on Growth Analysis of BPHTB and its Contribution to Local Taxes. The results showed that the contribution of taxes BPHTB to local taxes in South Tangerang city can increase local revenue each year, so run effectively. Furthermore, Witri, djudi, and Sulasmiyati (2016) examined the analysis of BPHTB outsourcing to the local government towards the local revenue in Bangkalan District. The results of the research indicate that Bangkalan Regency Government is not fully ready to receive BPHTB as the local tax.

\section{RESEARCH METHODE}

This study aims to see the extent to which the implementation of the policy of Acquisition of Land and Building Rights is implemented in Bandung. The method used in this research is descriptive with qualitative approach. Data collection techniques are conducted through observation, interviews and documentation. Informant's determination technique in this research use purposive technique, where informant taken is informant having information needed by researcher according to research purpose. The research informant consisted of the apparatus of local revenue management agency of Bandung City. Data triangulation techniques are used to test the validity of data. Data analysis is done through data reduction, data display, data verification and conclusion.

\section{RESULT AND DISCUSSION}

In Law Number 28 The year 2009 the tax is a compulsory contribution to the Region owed by an individual or a coercive body under the Act, by not obtaining direct remuneration and used for the purposes of the Regions for the maximum welfare of the people. Meanwhile, according to Soemitro in Mardiasmo (2011) "tax is the contribution of the people to the state treasury under the law (which can be enforced) with no direct revealing services that are used for public expenditures".

Bandung City for 6 years is very keen to explore the potential of local taxes for development activities. Local tax is compulsory dues made by an individual or an entity to the local government without direct referrals to be designated, which may be imposed under applicable laws and regulations (Darwin, 2010). The potential local taxes in Bandung City are from BPHTB sources. BPHTB is a central government tax delegated to the local government since the issuance of Law Number 28 The year 2009. This is of course very closely related to the implementation of the principle of decentralization, where the regions have the authority to regulate and manage their own areas in order for the community to be prosperous. In the implementation of the principle of decentralization, of course, the region needs funds from the regional income and expenditure budget which one of the sources is the local tax (Nurcholis, 2010). Local taxes are divided into two types: provincial taxes administered by provincial and district/municipality governments administered by district / municipal governments (Ilyas and Richard, 2013). Based on the observation, City Bandung has nine types of local taxes. BPHTB is a source of local taxes that ranks first in boosting local revenue. The results of the acquisition of the collection of land and building rights from 2011 to 2016 in Bandung can be seen in table 1 .

TABLE 1.Target and Realization of Revenue of BPHTB

\begin{tabular}{|c|c|c|c|}
\hline Year & $\begin{array}{c}\text { Target of Revenue of } \\
\text { BРНTB }\end{array}$ & $\begin{array}{c}\text { Realization of } \\
\text { Revenue of BPHTB }\end{array}$ & Achievements \\
\hline 2011 & Rp 232.000.000.000,- & Rp 306.250.907.376,- & $132 \%$ \\
\hline 2012 & Rp 240.000.000.000,- & Rp 398.574.514.052,- & $166,07 \%$ \\
\hline 2013 & Rp 350.000.000.000,- & Rp 415.761.410.854,- & $118,79 \%$ \\
\hline 2014 & $\operatorname{Rp} 439.650 .000 .000,-$ & $\operatorname{Rp} 418.787 .336 .368,-$ & 95,25 \\
\hline 2015 & $\operatorname{Rp} 428.150 .000 .000,-$ & Rp 399.885.860.295,- & $93,40 \%$ \\
\hline 2016 & $\operatorname{Rp} 660.000 .000 .000,-$ & $\operatorname{Rp} 440.329 .214 .279,-$ & $66,72 \%$ \\
\hline
\end{tabular}

Based on the above data, in 2016 BPHTB acceptance did not reach the specified target of $\mathrm{Rp} 660,000,000,000$, However, despite its performance achievement of $66.72 \%$ did not reach the target set, in 2016 it managed to achieve the increased realization of local tax revenue as much as Rp40 billion higher than the realization of local tax revenues in 2015.

If the result of analysis of the contribution of BPHTB to local tax in Bandung City, based on the result of research seen that BPHTB have big enough contribution to local tax, as in table 2 .

Table 2 BPHTB contribution to local tax revenue in Bandung

\begin{tabular}{|c|c|c|c|}
\hline Year & Revenue of BPHTB & Revenue of Local Tax & $\begin{array}{c}\text { Contribution } \\
\text { to local tax }\end{array}$ \\
\hline 2011 & Rp 306.250.907.376,-- & Rp 666.230.756.212,-- & $45,9 \%$ \\
\hline 2012 & Rp 398.574.514.052,-- & Rp 821.045.120.342,-- & $48,5 \%$ \\
\hline 2013 & Rp 415.761.410.854,-- & Rp 913.983.177.993,-- & $45,4 \%$ \\
\hline 2014 & $\operatorname{Rp} 418.787 .336 .368,-$ & Rp 1.400.523.790.573,- & $29,9 \%$ \\
\hline 2015 & Rp 399.885.860.295,-- & Rp 1.485.256.084.807,- & $26,9 \%$ \\
\hline 2016 & Rp 440.329.214.279,-- & Rp 1.721.690.086.831,- & $25,6 \%$ \\
\hline
\end{tabular}

Based on the above table it can be seen that there has been a dramatic decrease in BPHTB tax revenue achievement over the last three years, so BPHTB is only able to contribute $25.6 \%$ in 2016, but the realization of BPHTB revenue increases from year to year. The non-achievement of BPHTB revenue target according to the observation result is because the tax of BPHTB is the tax revenue result from the transaction of transaction and transaction of property done by the society which can not be predicted the incident. The transaction price is only Based on Reporting from Notary party, Officer of the land deed or National Land Agency and Price sale and purchase so far only based on the price The sale value of the tax object is not based on the price Value of the tax object.

Based on the results of observation, interviews with informants, the problems mentioned above due to the implementation of policies on BPHTB in Bandung is not fully 
implemented optimally. If reviewed from the rules related to BPHTB, the city of Bandung already has various rules on BPHTB, including rules that are technical nature of BPHTB collection procedures regulated in Mayor of Bandung Regulation No. 393 of 2012, and revised again with Mayor of Bandung Regulation No. 308 of 2013 and Bandung Mayor Regulation No. 308 of 2014.

Thus it can be said that not reaching BPHTB revenue target and decreasing contribution of BPHTB to local tax is very closely related to the implementation of the policy of BPHTB in Bandung not yet fully optimal. Whereas According to Waluyo (2011), local taxes have a dual role as a source of regional revenue (Budgetair) and as a regulator of the regional economy (regulated). Judging from the function of budgetary, tax is a tool to raise funds that will be used to finance government expenditures. While viewed from its function as regular (regulated), the tax is used as a tool to achieve certain goals that are located outside the financial field and the function of this set is directed to the private sector. It was also confirmed by Jones, Sally M \& Catanach, Shelley C. Rhoades (2004) that the tax will be a tool of the economic regulator and for development activities undertaken by the government.

According to Edward III (1980) policy implementation is crucial for public administration and public policy. Implementation of policy is the stage of policy-making between policy formation and policy consequences for the communities it influences. It is further said that there are four factors that influence the success of policy implementation, and these four factors influence each other. The four factors are communication, resources, disposition, and bureaucratic structure (Edward III, 1980). The assumption, if each factor or variable that can interact well then the policy objectives will be easy to achieve, and vice versa. Among these factors that are often considered very important are the communication and resource factors of the policy implementing organization. However, each of these factors is believed to have a very important role in the overall process of policy implementation.

The following will explain the four factors that affect the implementation of BPHTB policy in Bandung.

\section{A. Communication}

Policy analysis is the beginning, not the end, of efforts to improve the policy-making process and its results. That is why policy analysis is defined as communicating, or creation and critical judgment, knowledge relevant to policy (Dunn, 2003). Therefore, Agustino (2012) asserted that "Communication is one of the important variables that influence the implementation of public policy, communication is crucial to the success of achieving the objectives of public policy implementation". Effective implementation will take place if the decision makers know what they will do. Information known to decision-makers can only be obtained through good communication. Governments to implement policies should be transmitted to the right personnel and the order must be clear, accurate and consistent.

Based on the results of observations and interviews with informants, BPHTB policy in the city of Bandung has tried to be transmitted properly. But in its implementation in the city of Bandung has not fully the public have the awareness to pay taxes BPHTB. Taxes BPHTB is a tax that relies heavily on public awareness to pay for it. In addition, the support of infrastructure or communication facilities and infrastructure plays a role in the process of policy transmission, such as information technology infrastructure that proved very big role in the process of transmission or distribution of information in achieving the expected goals or targets, both in quality and quantity expected.

The support of communication facilities and infrastructure in implementing this BPHTB policy has been quite supportive. Bandung city to socialize taxes BPHTB through direct meetings with the community and socialization in 22 radio with a duration of 5 times a day. Besides, there are also outdoor activities for socialization. In the year 2017 has been done six times activities in Ujung Berung area, Karees area, and Bojonegara area. In this event conducted an interactive question and answer between the community with the apparatus from the field of planning and counseling agency revenue management area of Bandung city and regional apparatus in the district. This in accordance with the opinion of Siahaan (2010) states that on the imposition of Tax BPHTB, the subject of tax and Taxpayer refers to the same person or entity, where the subject and Taxpayer BPHTB is an individual or entity obtaining land rights and or building.

In addition to the media used in communicating BPHTB policies to be effective, the information submitted must be clear and consistent. Information BPHTB after the enactment of law number 28 of 2009 and city regulation Bandung number 2 in 2011, became the starting point of Bandung city to build communication with the community after the tax BPHTB out of taxes from the central government tax to the local tax. Therefore, based on the results of interviews with informants said that the clarity and consistency of BPHTB information is an aspect that is always considered, where the apparatus in charge of serving the tax BPHTB always provide information needed by the community either directly or indirectly, but on the other hand also found apparatus who are less responsible for implementing this policy.

Furthermore, in relation to this consistency factor, Winarno (2005) explains that the factors that encourage the lack of clarity of information in the implementation of public policy are usually due to policy complexity, lack of consensus on public policy objectives, the new and the tendency to avoid policy responsibilities. Thus, if viewed from the aspect of communication in implementing the policy BPHTB is not fully support BPHTB policy, because of the media socialization and not yet effective in conveying the contents of this policy.

\section{B. Resources}

Resources is an absolute requirement of the organization. Implementation of the policy will not be effective if the implementors lack the resources necessary to implement the policy. These resources comprise "Staff, information, authority, facilities; building, equipment, land and supplies "(Edwards III, 1980: 11). Implementation of BPHTB policy will certainly be successful if supported by sufficient resources. 
The city of Bandung in implementing BPHTB policy from the aspect of staff in quantity has personnel as many as 300 people, while the quality of the quality has not been fully qualified. Authority is a must-have resource for collecting BPHTB. Generally, the authority must be formal in order that the order can be implemented effectively. Authority is an authority or legitimacy for executors in implementing a politically determined policy. When authority does not exist, then the power of the implementors in the public eye is not legitimized, so it can derail the implementation of public policy. The authority to collect BPHTB is in the regional revenue management Department (BPPD). The authority of BPPD has been sufficient to support BPHTB policy implementation.

Physical facilities are also important factors in policy implementation. The Implementor may have sufficient staff, capable and competent, and may understand what to do, but without the support facilities (means and infrastructure), the implementation of BPHTB policy will not succeed. The existence of physical facilities in the form of adequate buildings to be something that is very important, as well as other physical facilities and infrastructure. Based on the results of observations and interviews with informants in implementing the policy BPHTB, Bandung has sufficient physical facilities supporting.

\section{Disposition}

Disposition is the tendency, desire or agreement of the implementers to implement the policy seriously what the policy objectives to be realized. There are two factors in the Disposition Effects Of Disposition and Incentives (Edwards III, 1980).

Disposition is defined as the attitude of the implementers to implement the policy, in the implementation of the policy if it wants to succeed effectively and efficiently. So the implementors not only know what they should do and have the ability to implement the policy, but they do and have a desire to implement the policy. The most important things in the disposition include Effect Of disposition, Incentives. Effect Of Disposition relates to the level of compliance of the implementers ie the tendencies of the implementer raises real barriers to the implementation of the policy. Whereas Incentives is the tendency that existing executors through incentives manipulation by policy makers through the advantages or costs will make the executor carry out his orders well.

Disposition is closely related to the character of the policy implementer. In implementing the BPHTB policy, honest, commitment and response characteristics are required. Based on observations BPPD apparatus has honest characteristics in working and serving the community. Based on the observations, the BPPD apparatus has not been fully committed and responsible for achieving the BPHTB target. This is evident from the decline in tax target BPHTB for the last three years. In another aspect, because BPHTB is a selfassessment system that has difficulty to achieve the targets that have been determined, would require more commitment and responsibility BPPD apparatus to achieve the target that has been determined.
Incentives as one of the aspects of the disposition that will make the policy implementer implement BPHTB policy well. Therefore, based on Bandung District Regulation No. 02 The year 2011, BPPD apparatus in charge of carrying out tax collection is given incentive. Provision of incentives is determined through the budget of regional income and expenditure. According to interviews with BPPD apparatus, it is said that incentives are given according to achievements, so the numbers are not always the same.

\section{Bureaucracy Structure}

Bureaucracy is one of the most frequent institutions even as a whole executing activity. Implementation of complex policies requires the cooperation of many parties. When a bureaucratic structure is not conducive to the implementation of a policy, it will lead to ineffectiveness and impede the course of policy implementation. The important things in the bureaucratic structure are Standard Operating Procedure (SOP) and Fragmentation. Standard Operating Procedures (SOP) are the mechanisms, systems, and procedures for the implementation of policies, the division of basic tasks, the functions of authorities and responsibilities implemented by policy implementers. While fragmentation is the spreading of responsibility for a policy among several organizational units by implementing the policy.

Bureaucratic structure in Bandung City in implementing BPHTB policy, its leading sector is in BPPD. In its implementation, BPPD is cooperating with regional apparatus to conduct BPHTB collection. Procedures for the collection of BPHTB according to Mayor's regulation No. 393 of 2012 that the taxpayer takes care of the Deed of Transfer of Land and/or Buildings through the Officials of the Land Actor (PPAT) or the Head of the Auction Office in accordance with the laws and regulations, then PPAT or Head of the Auction Office shall research on tax objects whose rights will be transferred.

According to the informants, the whole process of BPHTB collection activities can not be submitted or raised to third parties, except for activities in the process of collecting BPHTB in the form of application of information technology, printing of BPHTB forms, sending letters to taxpayers or collating data of BPHTB. In Article 4, it is said that the taxpayer calculates and fills out the Local Tax Payment Letters of BPHTB and pays the tax on the designated bank, PPAT or Head of Office in charge of the Auction signing the Regional Tax Payment Letters BPHTB, and Provision of the Regional Tax Collection Form BPHTB can organize by BPPD or PPAT. BPHTB Regional Tax Payment Letters are proof of payment or deposit of BPHTB which has been done by using the form or has been done in another way to the Regional treasury through the payment place appointed by the Mayor.

The Government of Bandung also does the raiding on taxpayers who have not made tax payments in accordance with the provisions. Therefore, in the year 2015 Forming the Regional Tax Control Team Bandung based on the Decree of Bandung Mayor Number: 973 / Kep.996-Disyanjak / 2015 About the Regional Tax Control Team Bandung 2015. This team formed with the aim of controlling entrepreneurs who have not registered himself as a Tax Payer; Implementation of order against Taxpayers alleged to have committed tax 
violations in accordance with the provisions of the legislation. Building an Online Tax System with Disyanjak Command Center (DCC) as an integrated information resource of the Tax Service Department, in which there are applications that directly interact with the community as taxpayers such as PEPES application (Earth Tax Service and Electronic Building System), where people can access data needs regarding the amount of tax value of the land and buildings based on the Tax Object Number (NOP), in addition to the installation of Tapping Box on the taxpayer self assessment as a comparison tool with the DSR (Daily Sales Report) / monthly reports that must be reported by the taxpayer as the basis for imposition of local taxes.

\section{CONCLUSION}

In the last three years, the Bandung City Government experienced a decrease in BPHTB tax target achievement, resulting in a decrease in the contribution of BPHTB to local taxes which also resulted in a decrease in local tax contributions to local revenue. non-achievement of BPHTB's revenue target due to taxes BPHTB is tax revenue result from transaction of transaction and transaction of property done by society that can not be predicted happened; Transaction price is only Based on Reporting from Notary party, PPAT or National Land Agency (BPN); and the selling price is only based on NJOP price not based on NOP price. Thus it can be concluded that the implementation of policy BPHTB in Bandung has not been effective due to communication factors, resources, dispositions and bureaucratic structures that have not been implemented with the maximum.

\section{ACKNOWLEDGEMENT}

Alhamdulillah, this article can be solved even with various shortcomings. Thanks to Allah Subhanahu WaTa'ala who has provided health, convenience, and smoothness for me. Thanks also to the Rector who has supported the publication of the results of this study. Thanks to the family who always gave me the freedom to be able to complete all the duties.

\section{REFERENCES}

[1] Agustino, Leo. Dasar-Dasar Kebijakan Publik. Alfabeta: Bandung. 2012.

[2] Darwin. Pajak Daerah \& Retribusi Daerah, Jakarta: Mitra Wacana Media. 2010.

[3] Dunn, William. Pengantar Analisis Kebijakan Publik. Yogyakarta:Gajah Mada University Press. 2003.

[4] Edwards III, George C. Implementing Public Policy. Washington: Congressional Quarterly Press. 1980.

[5] Hajarwati, Tri. Sosio Didaktika: Social Science Education Journal, 3 (1), 2016. page 50-61.

[6] Jones, Sally M \& Catanach, Shelley C. Rhoades. Pinciple of Taxation Advanced Strategies. New York: McGrawHill. 2004

[7] Ilyas, Wirawan. B, Richard. Hukum Pajak Teori, Analisis dan Perkembangannya. Jakarta: Salemba Empat. 2013.

[8] Mardiasmo. Perpajakan. Yogyakarta: Andi. 2011.

[9] Nurcholis, Hanif. Administrasi Pemerintahan Daerah. Jakarta: Universitas Terbuka. 2010.

[10] Rahayu, Siti Kurnia. Perpajakan Indonesia: Konsep \& Aspek Formal. Yogyakarta: Graha Ilmu. 2010.

[11] Siahaan, Marihot P. Pajak Daerah dan Retribusi Daerah. Edisi Revisi. Jakarta: PT. Raja Grafindo. 2010.

[12] Waluyo. Perpajakan Indonesia. Jakarta: Salemba Empat, 2011.

[13] Winarno, Budi. Teori dan Proses Kebijakan Publik. Yogyakarta: Media Pressindo. 2005.

[14] Witri, Djudi Mochammad, Sulasmiyati, Sri. Jurnal Perpajakan (JEJAK)| Vol. 9 No. 1 2016.Page 1-9 